\title{
A vingança e o sagrado no filme Abril Despedaçado. uma análise segundo o teórico René Girard
}

\author{
The Vengeance and the Holy in Abril Despedaçado Movie: An Analysis According \\ to René Girard
}

RESUMO

\begin{abstract}
Compreender que os símbolos e as metáforas presentes em uma produção audiovisual desvelam algum sentido primordial e mais profundo é uma forma de apreender como os significados são construídos no mundo, bem como o sentido do religioso derivado dessa construção. Sublinhar esses símbolos e metáforas presentes no filme Abril Despedaçado (2001) de Walter Salles, por intermédio dos sons, enquadramentos, luzes e diálogos entre as personagens, para compreender o sentido do sagrado e sua respectiva relação para com o ciclo de vingança da narrativa em questão é o que se objetiva nesse artigo. Para tanto, será articulada a teoria do francês René Girard (1923-2015), presente em seu livro $A$ violência e o sagrado (1990), possibilitando, assim, a articulação entre os temas da vingança, religião, sagrado e cinema. Sendo assim, metodologicamente, será apresentado o enredo, narrativa, símbolos e metáforas espaço-temporais do filme a fim de evidenciar a relação para com a teoria girardiana, em vista do refletir da seguinte questão: como o sagrado é manifesto na adaptação cinematográfica Abril Despedaçado (2001) de Walter Salles?
\end{abstract}

Palavras-chave: sagrado; vingança; cinema; religião.

\begin{abstract}
To comprehend that symbols and metaphors in an audiovisual production revels something primordial and meaningful is a way to apprehend how the meanings are built in the world, as well as the meaning of the religious derived from this world construction. To highlight these symbols and metaphors presented in the movie Abril Despedaçado (2001) by Walter Salles, through sounds, frames, lights, dialogues between the characters, to comprehend the meaning of the sacred and its relation with the vengeance cicle is the main goal of this paper. To aim that goal, it will be articulate René Girard's theory, presented in his book $A$ violência e o Sagrado (1990), in order to perceive the link between some subject-matter, as: vengeance, religion, sacred and cinema. Therefore, methodologically, it will be presented the plot, narrative, symbols and time-space metaphors to highlight the relation with Girard's theory, to think about the question: how is the sacred manifested in Abril Despedaçado (2001) by Walter Salles?
\end{abstract}

Keywords: sacred; vengeance; cinema; religion.

1 Doutoranda em Ciência da Religião pela Universidade Federal de Juiz de Fora - UFJF. Contato: maiara_miguel@yahoo.com.br. Artigo recebido em 17/03/2018 e aprovado em 22/10/2018. 


\section{Introdução}

Observar os cenários, luzes, sons, narrativas e enquadramentos de um filme importa àqueles que pretendem ver o que está além. Um diretor de cinema não pensa em cada detalhe e os aplica indistintamente. Ao contrário, há uma razão de ser e um propósito a ser cumprido considerando a história que se intenta narrar. Disso decorre que uma narrativa cinematográfica sempre dá ao expectador a possibilidade de ir além do que se mostra. $\mathrm{O}$ diretor de cinema brasileiro Walter Salles, em Abril Despedaçado (2001), adaptação cinematográfica inspirada no livro de mesmo nome escrito por Ismael Kadaré, valeu-se de sons, luzes, símbolos e personagens travestidas de ricas metáforas que sustentam uma narrativa profunda que, por sinal, desvela algo acerca do religioso -, olhar para esse aspecto é o nosso intento nesse trabalho.

Para Miguel Pereira, em seu artigo Abril Despedaçado: a saga do santo inocente (2011), é evidenciado que, embora a história seja adaptada do livro do albanês Ismael Kadaré, o espírito do original nas telas do cinema esteve preservado, quando salienta a realidade das vendetas. A adaptação transmutada da Albânia para o Nordeste brasileiro não foi aleatória. Para Pereira (2011), em especial, "[...] o eixo central da história passou por uma nova encantação cultural que se identifica com o espaço e o tempo de muitas e diversas culturas. A vendeta é um traço presente em todas" (PEREIRA, 2011, p. 63). Ou seja, não obstante, os processos particulares de materialização de um livro e um filme, não são eliminados o que pode estar dentro ou fora do sujeito, uma vez que a violência é uma realidade da vida comum. Portanto, o coração da narrativa de Kadaré por Salles é preservada e enriquecida. Há de se concordar com Pereira (2011, p. 63): há a encantação cultural evidenciada com novas personagens, como Pacu; bem como com o uso do símbolo da bolandeira, os enquadramentos da imensidão do sertão nordestino em contraste com a pequenez das personagens ali presas.

Tudo adquire um sentido que joga o expectador para o além. A bolandeira não é só uma bolandeira, a lua não é só um satélite natural de um planeta em um sistema solar, um balanço não é só um objeto para brincadeira. Salles não é o único a evidenciar a amplitude dos símbolos e metáforas, pois tal tema já havia sido trabalhado não só em produções cinematográficas, mas muito antes por teóricos da religião. A linguagem cinematográfica só reflete essa realidade já evidenciada por teóricos como Mircea Eliade e René Girard. De um lado, Mircea Eliade, por exemplo, em O sagrado e o profano (2010), rememora que "[...] para os apologetas cristãos, os símbolos estavam carregados de mensagens: mostravam o sagrado por meio dos ritmos cósmicos" (ELIADE, 2010, p. 115). Isto é, a água não era só um elemento natural essencial para manutenção de seres vivos, ademais, esse elemento passou a ser usado em rituais de batismo, indo além, desse modo, do sentido meramente físico. De outro lado, para René Girard, em $A$ violência e o sagrado (1990, p. 13-14), um assassinato pode ser um ato meramente físico e criminoso, porém, dependendo do rito empregado, aquele sangue que escorre pode conter uma significação que ultrapassa um crime. Esse sentido pormenorizado por Girard é o que será analisado nesse artigo, sendo articulado ao filme, seus símbolos e metáforas, em específico, na morte redentora da história contada por Salles, pois se vê uma violência que expia os problemas entre as famílias que protagonizam a narrativa, donde deriva o sagrado e o sentido do religioso presente no filme.

De modo introdutório, é reconhecido que os objetos carregam consigo certa ambiguidade: na mesma medida em que podem significar algo meramente físico e casual, podem, ainda, desnudar sentidos que carregam simbolizações culminantes no sagrado que, por sinal, possui estreita relação para com o que está no cerne do sujeito. Na produção cinematográfica de Salles o sentido da mensagem que se intenta comunicar e os símbolos adquirem vida própria. As camisas estendidas nos varais das famílias Breves e Ferreira, por 
exemplo, possui significância. A camisa, para a autora Guimarães, em Tempo, espaço, espectador e leitor: o Abril Despedaçado de Ismail Kadaré e de Walter Salles (2014), é uma personagem que logo no início da trama é enquadrada quando o menino Pacu, no ambiente do árido nordeste durante o amanhecer, introduz o expectador à trama e às personagens da seguinte maneira, considerando o roteiro registrado no livro Abril Despedaçado (2002)2- uma das referências principais desse artigo:

Meu nome é Pacu, é um nome novo, tão novo que eu ainda nem peguei costume. Tô aqui tentando alembrar uma história. Às vezes eu alembro... Às vez eu esqueço. Vai ver que é porque tem outra que eu não consigo arrancar da cabeça. É a minha história, de meu irmão... e de uma camisa no vento (SALLES; MACHADO; AINOUZ, 2002, p. 193, roteiro do filme).

A camisa no vento apresentada por Pacu não é só mais um item da vestimenta diária lavada e estendida para secar. Além disso, essa camisa passa a ser uma metáfora para o tempo da narrativa, assim como simboliza o estado da alma daquele que um dia a vestiu. A camisa é um dos exemplos que podemos sublinhar aqui, mas, para o bem desenrolar desse artigo, visamos olhar também para a bolandeira, os bois, o relógio, o balanço e alguns enquadramentos do sertão nordestino, em vista do que aqui se propõe questionar: como o coração dos símbolos e metáforas apresentados na narrativa de Salles desnudam o sagrado e sua respectiva relação para com o ciclo de vingança? Frederico Pieper, em seu livro Religião e Cinema (2015), ao apontar uma perspectiva existente de abordagem para compreender a articulação entre religião e cinema, sublinha que, "[...] o aspecto material exibido em um filme remete para além dele, em direção a uma realidade espiritual ou transcendente" (PIEPER, 2015, p. 31). Ora, então, como a realidade espiritual e transcendente que os símbolos acima listados remetem à quebra do ciclo de vingança e ao manifestar do sagrado?

Vale, ainda, ressaltar que além do atento olhar da obra de Salles e da interpretação dos símbolos apresentados, será exposta a teoria do francês René Girard (1923-2015), presente em seu livro $A$ violência e o sagrado (1990), em articulação com o filme, de modo que possibilite uma interpretação adequada acerca da relação entre vingança, violência e o sagrado. A escolha de Girard não é aleatória, uma vez que em seu livro, acima citado, se vê um estudo contundente sobre a relação da vingança, violência e o sagrado. Isso se justifica na medida em que aqui se busca, justamente, olhar para os sinais de tempo da narrativa contado na tela por Salles, que iluminam os ritos das famílias: os Breves e os Ferreiras e a maneira como se dá a quebra desse ciclo vingativo, coincidindo, assim, com o sagrado manifesto.

\section{Abril Despedaçado (2001) de Walter Salles}

A narrativa de Salles se passa no sertão brasileiro de 1910, em específico, em uma cidadezinha chamada Riacho das Almas, onde se vê duas famílias: os Breves e os Ferreiras3. Essas famílias protagonizam uma disputa por terra e honra presas em um ciclo de vingança

20 livro Abril Despedaçado (2002) foi dividido em três partes, sendo a primeira com o registro fotográfico do processo de produção do filme, a segunda parte com a narrativa de Pedro Butcher e Anna Luiza Müller, que conta a história do filme e a última parte, mas não menos importante, conta com o roteiro do filme escrito por Walter Salles, Sérgio Machado e Karim Aïnouz. Portanto, para diferenciar os momentos, a autora opta por referenciar Butcher e Müller quando houver citação da história, assim como será referenciado Salles, Machado e Aïnouz quando se trata da citação do roteiro do filme.

3 "Os Ferreira e os Breves chegaram à região do Inhamus - área seca e montanhosa no sudoeste do Ceará, fronteira com o Piauí - na segunda metade do século XVIII. Os Ferreira vieram do norte do Ceará, região do Sobral, e os Breves de Pernambuco e da Paraíba" (BUTCHER; MÜLLER, 2002, p. 91). 
tradicionalizado. Mas, não obstante esse cenário, tal história é inspirado no livro Abril Despedaçado de Ismail Kadaré. O romance de Kadaré se passa em meados de março no entardecer de um dia de inverno na cidade de Mirëditë, Albânia. Vê-se a personagem Gjorg Berisha na espera de sua vítima, Zef Kryeqyq. Gjorg está ali para vingar a morte de seu irmão e fazer cumprir a lei estabelecida pelo Kanun, "[...] um complexo código em forma de livro cujo conteúdo é mais poderoso do que as leis oficiais. Sua lei máxima é uma lei ancestral 'Sangue se paga com sangue'” (BUTCHER; MÜLLER, 2002, p. 77).

Walter Salles, antes de iniciar o empreendimento do filme, decidiu se encontrar com Ismail Kadaré. As reuniões instigaram Salles cada vez mais, que sublinhava que a narrativa não poderia ser transposta literalmente do livro para os cinemas ${ }^{4}$; ora, havia a necessidade de uma adaptação à realidade brasileira e a própria visão de mundo do diretor. No livro, Abril Despedaçado: a história de um filme (2002), uma das referências aqui já citadas e que será utilizada em todos os momentos, retrata esse processo de encontros entre Kadaré e Salles, bem como as instigantes decisões tomadas com o consentimento de Kadaré acerca da adaptação ao contexto do Nordeste brasileiro. Butcher e Müller, então, narram:

Comentamos os resultados das pesquisas, e Kadaré, como nós, ficou surpreso. Surgiram muitas semelhanças entre a vendeta no Brasil e a história que o livro narra. Em episódios como a ocupação do território do Inhamuns, no sertão cearense, vários crimes de sangue tiveram características iguais às descritas por Kadaré, constatou Walter Salles (BUTCHER; MÜLLER, 2002, p. 78).

Desse modo, a história adaptada por Salles é nosso objeto de análise, que narra a vida de duas famílias presa numa lógica de preservação de honra e terra por intermédio de um ciclo de vingança. Para Kadaré, segundo o que Butcher e Müller narram, ele foi o primeiro a reconhecer que essa narrativa poderia ser transposta para qualquer realidade "[...] onde existisse cobrança de sangue e lutas de família" (BUTCHER; MÜLLER, 2002, p. 79). Portanto, no filme de Salles vê-se, de um lado, os Breves, família composta pelo pai e mãe mais seus filhos que vivem da produção de rapadura.

Na narrativa de Salles, de um dos lados da história, contamos com a família dos Breves composta pelo pai, a mãe o filho do meio Tonho e o filho mais novo que passa a ter um nome somente no meio da narrativa, sendo ele Pacu. Além disso, contamos com uma camisa pendurada no varal do quintal da família dos Breves, simbolizando a alma daquele filho mais velho já morto, Inácio. Mas, do outro lado, contamos com a família dos Ferreiras composta por Isaías, o seu avô o Sr. Ferreira, o provedor e protetor da família, Mateus, outro neto do Sr. Ferreira e uma mulher, a viúva de Isaias, sendo estes duas últimas personagens responsáveis por relatar o tempo da narrativa ao Sr. Ferreira, bem como o cobrar a respectiva alma daquele que matará Isaias.

A narrativa de Salles, segundo Butcher e Müller (2002, p. 81-84) preserva o vermelho de Kadaré com a imagem da camisa pendurada com a mancha de sangue, apontando o fato de que uma morte já havia acontecido e que, muito em breve, o sangue do responsável por essa perda da família seria cobrado por Tonho. Gjorg de Kadaré passou a ser Tonho, filho do meio da família dos Breves, que ganha um irmão mais novo na produção de Salles, em vista de um olhar mais inocente. Ademais, a existência do irmão mais novo é decisiva para a resolução da trama, pois Tonho se encontra na dúvida de se manter na tradição da família e cobrar o sangue daquele que matou seu irmão mais velho, ao mesmo tempo em que anseia por sua

4 romance de Kadaré já havia sido adaptada duas vezes: “a primeira numa produção albanesa sem nenhuma repercussão mundial, e a segunda numa produção francesa, de 1987, com roteiro de Olivier Assayas e direção de Liria Bégéja. Nenhuma tinha deixado o escritor satisfeito" (BUTCHER; MÜLLER, 2002, p. 78). 
liberdade. Portanto, o irmão mais novo é aquele que sempre incentiva Tonho a abraçar sua liberdade. $\bigcirc$ pai de Tonho, que segundo Walter Salles, "[...] com sua face áspera, rude, seca e ríspida, seria 'o orgulho em estado puro"' (BUTCHER; MÜLLER, 2002, p. 83), ganha papel primordial na narrativa de Salles, ao contrário do que se passa na história de Kadaré. E a família Breves é o núcleo da narrativa; segundo Bucther e Müller (2002, p. 83) os Breves: "[...] possui uma fazenda com plantação de cana onde produz rapadura. Já gozaram de excelente situação econômica, mas agora estão em decadência. Seus rivais são os Ferreiras, fazendeiros de gado em situação econômica superior".

Abril Despedaçado de Salles ganhou novos contornos ao mesmo tempo em que ainda narra o conflito entre duas famílias que preservam a tradição das vendetas pela oralidade. Tonho é o responsável por vingar a morte do irmão mais velho que morreu. A camisa do irmão morto pendurada no varal é o marcador da trégua cedida dos Breves aos Ferreiras, sendo que quando o sangue amarela simboliza que é o momento de Tonho entrar em ação. Quando isso de fato ocorre, o pai dá orientações a Tonho. Ele empresta os sapatos e entrega a arma ao filho. Este, embora com medo, cumpre o que Ihe foi confiado e volta vivo para casa, mas sabe que sua hora vai chegar considerando que os Ferreiras Ihe deram uma trégua também indicada pela lua e pelo matiz de sangue da camisa que pertencia a Isaías, neto do Sr. Ferreira, estendida no varal da fazenda dos Ferreiras.

O irmão mais novo o orienta fugir, mas Tonho se mantém pensativo, até o momento em que parte para o circo presente no centro da cidade e se encontra com Clara, jovem mulher com quem ele se envolve emocionalmente. Mesmo sabendo de sua função no cumprir desse sistema de vendetas ensinado pelo orgulhoso pai, ele parte para essa aventura. Tonho passa um tempo com Clara, mas volta para casa para cumprir seu destino. Clara chateada, em uma noite depois de um dos espetáculos do circo ao qual fazia parte, decide partir em vista de Tonho. Ela chega até a casa de Tonho, o encontra e vão para a casa da rapadura. Enquanto os dois estão lá, o irmão mais novo assiste a chuva, enquanto o neto de Ferreira, Mateus, está à espreita para matar Tonho. O irmão mais novo nota isso e sabe que ele está ali para matar Tonho, que carregava em seu braço uma faixa preta indicando sua morte. Então, o irmão mais novo, depois de avistar Clara saindo da casa de rapadura, vai até à casa de rapadura, toma as roupas e se veste com os trajes do irmão, inclusive a faixa preta, e começa a caminhar na caatinga. $\bigcirc$ neto de Ferreira, Mateus, estava com a visão comprometida, ora por razão da chuva, ora porque havia derrubado seus óculos e os havia quebrado. Então, ao invés de matar Tonho, ele acaba por matar o irmão mais novo, Pacu.

O irmão de Tonho, então, é imolado para expiar esse ciclo de vendetas. Com isso, o pai e a mãe caem em desespero, ao passo que assistem Tonho ir embora ao encontro de sua liberdade. Segundo Butcher e Müller (2002), o irmão mais novo, Pacu possui uma função muito importante, pois:

Pacu é o agnus dei, cordeiro de Deus, "o cordeiro sacrificial que lava, com seu sangue, o pecado dos outros. Límpido, sem máscara, o menino é o único que consegue ver além das cercas que definem o mundo dos Breves. É o único que, de alguma forma, domina a palavra, e a usa para se projetar no território dos sonhos e da imaginação", como explica o diretor [Salles] no texto Aos amigos de Abril (BUTCHER; MÜLLER, 2002, p. 83).

Portanto, uma das diferenças notadas entre Kadaré e Salles é, justamente, a presença do irmão mais novo, Pacu, que passa a ser o imolador. Ele é o responsável por colocar para fora todo o caos que aquele ciclo de vingança traz, assim como é o responsável por libertar Tonho desse sistema opressor, que o mantinha na dúvida entre sua liberdade e a tradição da família. Após o sacrifício - (ou, o sagrado), então, Tonho se dirige ao mar e se lava. Ele, renascido, 
desse modo, se dirige para longe desse ciclo tradicional de cobrar sangue. Ora, mas ainda nos cabe uma questão importante: se a quebra desse ciclo vingativo culminou no sagrado, a saber, a imolação de Pacu, então, como os símbolos retratados na produção cinematográfica de Salles iluminam a quebra do ciclo vingativo e o sagrado?

\subsection{A relação dos símbolos com a vendeta}

A trama começa com a personagem do menino Pacu caminhando no amanhecer, se apresentando e expondo a camisa ao vento. Tal camisa pertencia ao irmão mais velho da família Breves, que morreu pela bala dos Ferreiras que cobravam o sangue. A camisa suja de sangue no vento, apresentada logo nas primeiras tomadas com uma cortina de transição do Pacu para Tonho e de Tonho para Pacu, segundo a autora Guimarães (2014, p. 27) é o marcador da trégua, ou seja, aponta o momento em que Tonho, o irmão do meio dos Breves, deve vingar a morte de seu irmão mais velho, Inácio. O responsável por enfatizar o sentido dessa camisa é o pai, símbolo da tradição do aprisionamento nesse sistema de vinganças que rememora durante um jantar que a camisa amarelou. A passagem da cor vermelha para o amarelado do sangue que suja a camisa importa para essa trégua, pois quando atinge o matiz amarelado é significado que a alma do morto ainda não encontrou paz e descanso; portanto cabe a Tonho vingar a morte desse irmão em vista do encontro da paz do falecido.

É interessante observar o modo como Salles escolheu para simbolizar esse ciclo de vingança fechado, em especial, os símbolos que fazem a marcação de tempo, uma vez que todos sublinham o subtrair e esgotar não só da vida de Tonho, mas, sobretudo, da própria tradição que o pai intenta preservar. Esse sistema de vendeta não é só representado pelo olhar rígido do pai, já que a bolandeira, assim como Guimarães (2014, p. 79) ressalta, é também um símbolo desse ciclo infinito de vinganças tão presente no filme. Em nossa interpretação, a bolandeira possui relação com a camisa estendida no varal também, uma vez que ambos apontam para as noções de tempo da trama. Mas, no caso da bolandeira, diferentemente da camisa, ela sublinha o papel de cada membro da família no preservar da honra através do cobrar do sangue, bem como o esgotamento desse sistema. Ao passo que a camisa, por sua vez, sublinha o período da trégua dado e o momento exato que se cobra o sangue daquele que um dia usou essa camisa. Isto é, a camisa integra o rito dessa tradição de vinganças.

A família dos Breves planta cana e se sustenta com os lucros obtidos da rapadura produzia por eles. A bolandeira é o meio de moer a cana colhida para o ferver do caldo que, passado de um tacho a outro, engrossa, depois talha, é enformado como rapadura e vendido. Esse é o sentido da subsistência para a família que a bolandeira exerce; todavia, a bolandeira vai muito além. Guimarães $(2014$, p. 79-80) ilumina o fato de que a bolandeira sempre vira para o sentido anti-horário e enquanto marcador de tempo sempre subtrai, representando, desse modo, o esgotamento desse modo de vida. Quem gira a bolandeira é o pai, responsável pela respectiva manutenção do ciclo de vingança em vista da manutenção da honra dos Breves. $O$ responsável por colocar a cana para moer é Tonho, que simboliza o papel ativo no cobrar o sangue do irmão morto pela bala dos Ferreiras. A mãe recolhe o bagaço da cana, que na trama da família é responsável por recolher o bagaço dos corpos dos filhos falecidos. Pacu, o menino, carrega a cana para Tonho, trazendo a lembrança de que um dia quem irá moer a cana para manter a tradição e honra da família será ele.

A bolandeira, como já mencionado, gira sempre no sentido anti-horário, simbolizando o relógio da vida que está sempre a subtrair. Ou seja, é a vida que roda para traz nesse ciclo de vingança. No roteiro de Salles a bolandeira, então, assume o papel de "[...] um relógio primitivo, que marca inexoravelmente a passagem do tempo" (BUTCHET; MÜLLER, 2002, p. 193). Os bois carregam a responsabilidade do mundo e o sentido anti-horário é o próprio esgotamento do ciclo de vinganças. Os roteiristas do filme, no livro do filme Abril Despedaçado (2002), ainda ressaltam que ao lado do esgotamento desse sistema há a marca da 
opressão sobre os Breves, que sempre se vêem presos entre as engrenagens desse mecanismo que, propositalmente, Salles retrata rememorando as engrenagens de um instrumento de tortura medieval. E, sobre o papel do engenho de cana, os roteiristas ainda reiteram:

Com seu mecanismo peculiar, a bolandeira deu corpo ao ciclo do tempo e à opressão que pesam sobre os Breves. Quando Tonho, o protagonista, obedece aos anseios da família e vinga a morte do irmão mais velho, sendo capturado pelas engrenagens do círculo de vingança, passa ter data certa para morrer. A partir daí é como se o tempo, para ele, contasse para trás (SALLES; MACHADO; AIINOUZ, 2002, p. 8688 , roteiro do filme).

A bolandeira é enquadrada durante todo o filme sempre simbolizando o papel de cada membro da família dos Breves na roda da vingança e o tempo que se esgota para Tonho, pois Tonho vinga a morte do irmão e mata o neto do Sr. Ferreira, Isaías. Ou seja, Tonho está preso nas engrenagens desse moinho. Todo esse processo se desenrola pelo obedecer das orientações dadas sempre pelo pai. O pai empresta sua bota e dá a arma a Tonho. Quando o pai descobre que Tonho matou aquele que havia matado seu outro filho, ele, então, orienta Tonho prestar sua homenagem ao morto. Tonho vai ao enterro, almoça com a família Ferreira e, ao ir embora, pede a trégua ao Sr. Ferreira, o avô de Isaías. Nesse momento, vê-se o Sr. Ferreira, que é cego, caminhar para dentro de sua casa em busca de uma faixa preta para marcar Tonho. Tudo se passa pelo som do tique-taque do relógio que parece ser protagonista no momento. Então, o Sr. Ferreira coloca a faixa preta em Tonho e sublinha que o tempo dele é sempre "menos um, menos um, menos um" até o final da trégua concedida, que será medida pela lua cheia e pelo amarelar da camisa de seu neto estendida em seu varal.

AVÔ DE ISAÍAS: Tu tá vendo aquele relógio ali?

Tonho vira o rosto. Do seu ponto de vista: um relógio de parede, os ponteiros avançam inexoravelmente.

AVÔ DE ISAÍAS: Cada vez que ele marcar mais um, mais um, mais um... ele vai tá te dizendo menos um, menos um, menos um (SALLES; MACHADO; AIINOUZ, 2002, p. 202, roteiro do filme).

O tempo para Tonho é primordial e pode ser analisado em relação com as camisas estendidas no varal simbolizando o período da trégua, a bolandeira sempre a trabalhar em sentido anti-horário como uma ampulheta, as engrenagens que o prendem nesse sistema vingativo, e o relógio que a cada tique-taque relembra Tonho do esgotamento de sua vida. Sendo assim, o protagonista está preso nesse sistema de vingança. Pacu, seu irmão, no início do filme pede para Tonho não vingar o irmão, ao contrário do que o pai orienta. Após a morte de Isaias, Pacu aconselha Tonho a ir embora e fugir. Pacu é a imagem daquele que quer quebrar o ciclo dessa tradição vingativa que, em um determinado momento do filme diz: "[...] a gente é que nem os boi: roda, roda e nunca sai do lugar" (SALLES; MACHADO; AIINNOUZ, 2002, p. 208, roteiro do filme). A comparação feita por Pacu sobre a realidade de sua família e os animais que rodam pode ser vista, talvez, como o início da quebra do ciclo da vingança.

Os bois e a bolandeira aparecem em diversos momentos da trama, mas há um momento em particular que merece menção de acordo com Guimarães (2014, p. 80). Depois de um longo dia de trabalho moendo as canas e os bois determinando o ritmo da bolandeira, Pacu se assombra com o fato de os bois estarem rodando sozinhos e avisa Tonho. Nesse momento, de acordo com o enquadramento da câmera, Tonho está segurando a canga (pedaço de madeira que prende os bois). Quando Tonho olha para essa cena, decide que não vai ficar girando como os bois, ele joga a canga no chão, vira as costas e vai ao encontro de 
Clara, que trabalha no circo que chegou à cidade vizinha. Noutras palavras: Tonho nega seu destino de rodar como os bois naquele ciclo que subtrai o tempo de sua vida.

Esse é um momento de grande tensão para os Breves, que temem pela defesa de sua honra por intermédio daquele que não está mais ali. Pacu rejubila-se com a decisão do irmão, quando em um dia acorda e não vê mais o irmão dormindo na cama ao lado. Enquanto isso, Tonho está a viajar com o circo como ajudante, ao lado de Clara, com quem está envolvido emocionalmente. Até esse momento ainda constam dois símbolos importantes que merecem ser explorados: o balanço de Pacu e a Lua. A Lua sempre foi também uma espécie de marcador de tempo escolhido por Salles, sendo ela sempre aparente em cortes e focos específicos, mantendo desse modo a noção do tempo que se esgota. Já o balanço, segundo Guimarães (2014, p. 90-93), atua como a ampulheta que, entre uma tomada e outra, marca o tempo de Tonho.

Na sequência em que Tonho viaja para vingar seu irmão, por exemplo, as tomadas iniciam-se na madrugada de um dia, ainda escuro, e só terminam quando ele atinge seu destino, no anoitecer daquele dia. Entremeadas a essas sequências aparecem tomadas de Pacu brincando nervosamente no balanço da família, entrando e saindo do enquadramento da câmera. A sensação evidente é a de um pêndulo de relógio, que aguarda ansiosamente o sucesso, ou não, da empreitada (GUIMARÃES, 2014, p. 93).

Sendo assim, essa brincadeira também funciona como uma ampulheta, pois na lacuna de tempo em que Pacu aguarda Tonho voltar vivo se vê o balanço indo e voltando; alternando, desse modo, o movimento de câmera que ora foca o céu e ora foca Pacu tenso. Quando Pacu vê o irmão voltar vivo, ele pula do balanço e abraça o irmão, saindo, assim, desse período de tensão por causa da tensa empreitada de seu irmão.

O romper com o sistema de vingança é o que nos importa e, tendo em mente os símbolos, objetiva-se, agora, notar como se dá esse romper. Há de ser considerada a importância de Tonho ao reconhecer que não quer mais girar como os bois ao jogar a canga no chão e enveredar para o local em que Clara está. Tonho, desse modo, passa a ajudar nos afazeres do circo a ponto de viajar para a cidade vizinha para acompanhar um espetáculo. Quando ele, junto com Clara, chega à cidade de destino, montam os aparatos do circo. Nesse momento, Clara avista uma corda, a câmera a foca subindo nessa corda e pedindo ajuda para Tonho; na sequência ela pede para que Tonho a gire e, então, Salles nos presenteia com uma transposição de tempo belíssima, enquanto Tonho assume o girar do tempo que se perde na imagem de Clara que flutua no ar.

O rosto de Tonho permanece imantado. Clara dá a impressão de estar solta no ar, como se estivesse voando. O rosto de Tonho demonstra o estado de transe em que vê... O corpo de Clara contra o céu azul, como se fosse uma ilusão de ótica. Do ponto de vista de Tonho: ele tem a impressão real de que Clara vence a lei da gravidade e começa a flutuar. Fusão para a corda indiana que continua girando, mas agora já é noite. O tempo passou, sem que os dois tivessem percebido (SALLES; MACHADO; AIINOUZ, 2002, p. 219, roteiro do filme).

Nesse momento, é Tonho quem assume o movimento de algo cíclico. Ele gira Clara seguindo as orientações dela, se perdendo, dessa forma, nos movimentos dela que a cada momento parece estar mais rápida e desprendida da corda, fazendo com que pareça que ela está flutuando. Nesse instante, Tonho perde, de certa forma, a noção de tempo, a ponto de o 
luar descer e ele, ainda, por alguns momentos, se encontrar extasiado com a imagem de Clara que flutua. Mas não obstante o assumir do tempo por Tonho, ele rememora Clara que precisa voltar para sua casa para cumprir seu objetivo.

No momento em que Tonho joga a canga no chão se inicia o momento da ruptura com essa "bolandeira", ou seja, com esse sistema de vinganças. Na sequência, vê-se Tonho tomando em suas mãos o tempo, que se perde diante de seus olhos que fitam Clara flutuar no céu. Ora, mas por que o aspecto religioso possui relação para com a quebra do ciclo de vingança? Como, então, se dá o sagrado na narrativa de Salles?

\section{A vingança, violência e o sagrado em René Girard}

Entender que René Girard (1923-2015), teórico contemporâneo francês, analisou textos literários, mitos, descrições etnográficas, textos bíblicos e de livros sagrados de diversas tradições religiosas, que, por sua vez, contribuiu no elaborar de sua teoria mimética, bem como nos pormenores no modo como vingança, violência e o sagrado se dão importa. Contudo, em vista do que se objetiva aqui, daremos maior importância à relação entre vingança, violência e o sagrado. Mas, antes, é necessário entender que para Girard os sujeitos não são autênticos e buscam preencher essa lacuna através de algum objeto.

É no texto Mentira Romântica e Verdade Romanesca (2009, p. 25-75) onde Girard melhor descreve que os sujeitos desejam algo; porém, esse desejo é sempre intermediado por um modelo. Em situações ideais, o sujeito diz em alto tom que anseia por determinado objeto porque quer imitar um modelo. No entanto, há casos em que o sujeito quer o objeto e tão somente o objeto e, por isso, ao invés de idealmente imitar seu modelo, ele passa a hostilizar esse sujeito que se coloca como modelo-obstáculo de seu desejo, uma vez que esse sujeito o impede de possuir o que tanto quer. Aqui então residem competição e hostilidade de um contra o outro, culminando em grandiosa crise e violência que precisa ser colocada para fora. Ora, mas como isso se dá? Para tanto, faz-se necessário olhar atentamente para o que Girard desenvolve em seu texto $A$ Violência e o Sagrado (1994) onde, logo de início, ele enfatiza:

A violência não saciada procura e sempre acaba por encontrar uma vítima alternativa. A criatura que excitava sua fúria é repentinamente substituída por outra, que não possui característica alguma que atraia sobre si a ira do violento, a não ser o fato de ser vulnerável e de estar passando a seu alcance (GIRARD, 1994, p. 14).

Noutras palavras: da situação de grandiosa hostilidade e rivalidade entre os sujeitos é desencadeada o que Girard chama de crise sacrificial, ou seja, o caos eminente em que as diferenças são apagadas e a violência valoriza os atos e decisões dos sujeitos. Essa violência não saciada desse clima de caos, de acordo com a teoria de Girard, precisa ser saciada e isso se cumpre quando é apresentada uma vítima que coloque para fora todo esse caos. Mas essa vítima não é a responsável por causar todos esses problemas e desavenças, mas sim uma vítima inocente que desvia essa violência anárquica e proteja a comunidade, ou seja, um sacrifício. Por isso, Girard (1994), rememora:

[...] o sacrifício apresenta-se de duas maneiras opostas: ou como 'algo muito sagrado', do qual não seria possível abster-se sem negligência grave, ou, ao contrário, como uma espécie de crime, impossível de ser cometido sem expor-se a riscos igualmente graves (GIRARD, 1994, $\mathrm{p}$. 13). 
Disso decorre que o sacrifício só é sagrado quando esse ato, considerado ato social pelo autor, elimina qualquer tipo de consequência que possa reacender grandioso caos novamente, uma vez que seu objetivo é apaziguar os ânimos. Mas, quando apresenta consequências, o ato não foi cumprido como deveria, fazendo com que o caos se mantenha. Ora, mas quais são os riscos e consequências graves que esse ato social deve eliminar? São os sentimentos que sustentam a rivalidade entre os sujeitos. Os sentimentos da inveja, cobiça, malícia, vingança e etc., que alimentam o clima de tensão que culmina na violência que deve ser expiada pelo sacrifício.

O recalcar dos sentimentos da inveja, cobiça, malícia, vingança e etc. alimenta o ímpeto dos golpes de um contra o outro em busca do objeto que o sujeito deseja. Quanto maior a velocidade desses golpes, maior o caos e mais eminente a violência intestina nessa realidade. Portanto, não seria grandiosa surpresa que em quadros rituais primitivos a vingança seria tratada como assunto sério que deve ser evitado. Aos olhos de Girard (1994, p. 28): "[...] quando a violência recalcada pelo sacrifício releva um pouco sua natureza, ela se apresenta sob a forma de vingança do sangue, do bloodfeud'. Sendo assim, em qualquer lugar que em que a vingança se mostra, ela é terminantemente proibida, porque ela constitui "[...] um processo infinito, interminável". Ademais, Girard (1994) sublinha:

[...] quando a violência surge em um ponto qualquer da comunidade, tende a se alastrar e a ganhar a totalidade do corpo social, ameaçando desencadear uma verdadeira reação de cadeia, com consequências rapidamente fatais em uma sociedade de dimensões reduzidas (GIRARD, 1994, p. 28).

Essa reação de cadeia é desencadeada sempre que sublinhado a necessidade de matar aquele que matou. Ou seja, segundo Mark R. Anspach, em seu livro Anatomia da vingança (2012, p. 21-23), a vingança de um assassinato é o primeiro círculo vicioso que se engendra, do qual a humanidade precisa escapar. Quando a primeira morte do ciclo se inicia, há um equilíbrio momentâneo; porém, tal equilíbrio se quebra logo quando é sentida a necessidade de matar aquele que matou. Desse modo, podemos concordar com Anspach (2012), a vingança se sustenta por intermédio de uma premissa quase matemática: vingança = matar (aquele que matou), que passa a ser autorrefencial, porque matar (aquele que matou) = matar (o operador da vingança). Ademais, segundo Anspach (2012) "[...] uma vez concretizada a vingança, o equilíbrio perdido é restaurado, mas, assim que é restaurado, é novamente ameaçado, porque as pessoas próximas do assassino morto desejarão aplicar a mesma palavra de ordem: matar aquele que matou" (ANSPACH, 2012, p. 22). Sendo assim, há uma oscilação entre os papeis durante esse ciclo representado por diversos agentes durante esse círculo que se perde no tempo e que ameaça toda uma comunidade. $O$ vingador encarna a vingança que, dentro desse ciclo, torna-se automaticamente marcado como próxima vítima que será morta por uma agente que cobra o sangue daquele que matou. Em suma,

A vingança não consegue restaurar o equilíbrio entre grupos que o ato do primeiro assassino perturbou, pois cada novo assassino que ela produz sempre é excessivo. O ajuste de contas continua, pois o medido nunca volta ao zero. $O$ último que matou sempre deve pagar. A operação da vingança faz oscilar a dívida sucessivamente de um lado para o outro sem nunca parar num ponto de equilíbrio (ANSPACH, 2012, p. 23).

Portanto, para Girard (1994), o domínio do preventivo é primordial, em especial, quando deve haver uma violência que apresente uma vítima que possa expiar os problemas de 
uma comunidade assolada por um ciclo de vingança, por exemplo. A prevenção que se intenta habita, sempre, o âmbito do religioso, pois o sacrifício é da ordem do religioso, na medida em que se mostra viabilizado por um quadro ritual. Sem rito o sacrifício é só um ato violento que sustenta o ciclo vingativo. Ao passo que, quando o rito é religiosamente aplicado, o sacrifício exerce seu papel primordial de eliminar qualquer consequência, como a vingança, e, desse modo, restaurar a comunidade que se perdia na violência recíproca e vingança.

A prevenção religiosa pode ter um caráter violento. $A$ violência $e \quad 0$ sagrado são inseparáveis. A utilização "ardilosa" de certas propriedades da violência, e em especial de sua capacidade de deslocar-se de um objeto a outro, dissimula-se por trás do rígido aparato do sacrifício ritual (GIRARD, 1994, p. 33, grifo nosso).

Aqui, então, Girard reitera que não há o elemento do sagrado sem a violência, uma vez que são inseparáveis. Mas, o que faz a violência ser sacrificial ou não é o rígido aparato ritual que a legisla. $\bigcirc$ rito integra o âmbito da linguagem da experiência religiosa, pois, através do rito, de acordo com Croatto, em seu livro As linguagens da experiência religiosa (2010, p. 329-392), é permitido o participar do divino, noutras palavras: o possibilitar da comunhão com o elemento transcendente. Se o sacrifício é um ato social para Girard, então pode-se dizer que o rito é uma expressão coletiva que permite a comunhão com o transcendente que se dá por intermédio do sacrifício. Para Girard (1994, p. 34), por sua vez, “[...] o religioso sempre procura apaziguar a violência e evitar que ela seja desencadeada". Isto é, na medida em que, por intermédio do ato de fazer o imolado ser sagrado, que se dá a possibilidade da quebra do ciclo vingativo que ameaça o existir de uma associação humana. Portanto, "[...] sacrifício reencontra a totalidade da vida moral e religiosa, mas somente após um desvio bastante extraordinário" (GIRARD, 1994, p. 34). Desviar dos sentimentos que valorizam os objetos desejados e a hostilidade entre sujeitos que desejam esses objetos que culmina em grandiosa desavença e violência recíproca é o objetivo do sacrifício. Ao mesmo tempo em que é um assassinato por razão do rito, que visa tornar sagrado, esse sacrifício passa a ser religioso, pois no escorrer o sangue do imolado que permite a comunhão com o transcendente é que se vê, desse modo o sagrado.

Mas, além disso, deve ser considerado que o sagrado, do ponto de vista girardiano, é também a violência dos próprios homens, uma vez que, se a realidade da violência é algo que domina a realidade dos homens, então passa a ser algo que estes desejam dominar. Compreender o sagrado fora do âmbito da violência para Girard não é possível por duas razões: (1) o sagrado é ambíguo porque depende do sacrifício que é uma violência, mas se presta ao objetivo de santificar o sangue daquele que foi imolado; (2) "[...] a alma secreta do sagrado é a violência" (GIRARD, 1994, p. 47), na medida em que é uma realidade que deseja ser dominada pelo homem. Disso decorre, então, que o ato do sacrifico, embora seja ambíguo, é um ato social legitimado por um rito que visa dominar um problema que assola uma associação humana. Portanto, o sagrado se concentra ali, na quentura do sangue que escorre sacralizado pelo rito que visa dominar a violência que domina o homem. Ora, como essa teoria sobre o sagrado e a violência se relaciona com a realidade do filme Abril Despedaçado de Walter Salles?

\section{Abril Despedaçado de Walter Salles e o Sagrado}

Se a relação entre sujeitos em uma associação humana possibilita o desencadear de hostilidades e ressentimento, a ponto de calcificar a realidade violenta segundo Girard, não poderia tal realidade ser identificada na narrativa de Salles? A violência e a vingança são realidades da história contada nas telas, que se dá pela rivalidade entre a família dos Breves e 
dos Ferreiras. Ambos brigam por honra e terra. Ambos desejam algo e rivalizam por esse objeto que tanto anseiam. $O$ irmão mais novo, Pacu, elucida essa briga entre as famílias da seguinte forma:

MENINO [em off Os Ferreira tomaram, e nós tomamos dos Ferreira... Agora é deles de novo. Foi assim que começou a briga. Pai diz que é olho por olho. E foi olho de um, por olho de outro... olho de um, por olho de outro...que todo mundo acabou ficando cego (SALLES; MACHADO; AIINOUZ, 2002, p. 196, roteiro do filme).

Nesse pequeno excerto do roteiro se vê a relação triangular: os Breves, os Ferreira e as terras e honra. Além disso, é visualizada a lógica do clico de vingança que permeia toda a história dessas famílias. A terra foi dos Breves, depois o Ferreira as tomou e assim se engendrou a briga, que, segundo o menino, seguiu a lógica do "olho de um, por olho de outro". Isto é, a premissa autorreferencial da vingança é visualizada na trama. Sempre há a necessidade de matar (aquele que matou). Sempre se intenta eliminar o assassino, donde decorre a oscilação de papeis do agente que cobra o sangue: no início do filme se vê os Ferreiras cobrando o sangue ao matar Inácio, o filho mais velho dos Breves, e a camisa com o matiz vermelho de sangue como cortina de transição apresentando, logo no início do filme, as figuras do pai, de Tonho e do menino. Por conseguinte, logo depois se vê Tonho matando o neto do Sr. Ferreira e, na sequência, Tonho marcado para morrer preso nas engrenagens desse ciclo ao mesmo tempo que almeja a liberdade. Aqui, então, se vê a grandiosa crise excitada pelos ciclos de vingança que coincide com o que Girard intitula crise sacrificial. Ao invés do ato de matar servir como apaziguador dos ânimos e congregador das famílias, ao contrário, servem como uma ofensa suprema que exige cobrança. Nesse sentido, a violência é ilegítima e não-sacrificial, a ponto de o menino anunciar: "olho de um, por olho de outro... que todo mundo acabou cego". O final cego de todos é o eminente acabar com as esperanças da associação humana que atuou como agente nesse ciclo vingativo.

A bolandeira simboliza o rito que existe na vida dos Breves, assim como os marcadores de tempo: camisa estendida no varal e lua exercem influência nos atos dessa vendeta tradicionalizada. A bolandeira apresenta o papel do pai como o orientador e mantenedor da tradição e honra ao passo que ele guia os bois. Tonho é o agente que deve cobrar o sangue na medida em que é aquele que coloca a cana para moer. A mãe é a responsável por recolher o bagaço, o que sobra dos corpos e orar por suas almas. Por fim, o menino, que entrega a cana a Tonho, representando que um dia substituirá o irmão que hoje é responsável por moer a cana. Esses são os agentes nesse ato sacrificial donde não se vê o sagrado, senão somente uma suprema ofensa. A camisa estendida no varal junto com a lua simboliza o tempo da trégua e o instante correto para cobrar o sangue do outro.

Tonho tinha o tempo do amarelar da camisa de Isaías estendida como relógio que se move a cada brisa que a toca. Mas a esposa de Isaías, bem como Mateus, que não haviam concordado com a decisão do Sr. Ferreira de ceder esse tempo a Tonho, decidem, desse modo, enganar o avô que é cego. A camisa, embora ainda estivesse avermelhada, é descrita com o matiz amarelado e, então, o Sr. Ferreira enganado orienta Mateus: é a hora! Mateus assume o seu papel dentro desse ciclo de vendetas. Aqui, desse modo, se vê a oscilação dos agentes nesse ciclo vingativo perdido no tempo, bem como a quebra de regras que culmina, nesse caso, em nossa interpretação, no ato que permitirá consagrar o sangue do imolado em vista do sagrado. Ou seja, esse ato negligente da família Ferreira propicia a quebra do ciclo vingativo e a liberdade de Tonho. Em virtude dos ânimos excitados e acelerados de Mateus e da esposa de Isaias, Mateus acaba sendo negligente no momento de cobrar o sangue de Tonho, o que permite, assim, a efetividade da substituição sacrificial. 
É óbvio que a substituição sacrificial que se dá na narrativa não ocorre somente devido à negligência de Mateus no momento em que vai matar Tonho e acaba por se confundir. Mas sim pela presença do irmão mais novo, o menino, ou, ainda Pacu. Esse menino desde o início simbolizou a quebra da tradição das vendetas. Quando o pai orienta Tonho matar Isaias, o menino intervém e pede ao irmão para não o fazer. Mesmo depois de isso ocorrer, ele orienta Tonho fugir e sempre aponta para dimensão em que a família se situa: girando sem sentido igual aos bois. É o menino que sublinha o esgotar da família e a contagem regressiva que a família se movimenta ao comparar com o movimento dos bois. O próprio Salles ressalta que o menino é o único que domina a linguagem e consegue se lançar para além do espaço e tempo em que ele se localiza. Ele sempre teve o papel da transgressão. Por isso, não seria grandiosa surpresa ele decidir morrer no lugar de Tonho para garantir a liberdade do irmão.

Salles decide por alternar planos abertos e mais fechados para retratar o árido sertão Nordestino. Nos planos abertos se vê as imensas paisagens da aridez do sertão com a imagem pequena dos sujeitos que nele habitam. Essa vastidão é o espaço que deseja ser conquistado. $O$ menino sempre provoca Tonho para se aventurar nesse vasto espaço que, embora amplo, grande e difícil de atravessar, possibilita a liberdade do mesmo. Ao passo que Salles marca o tempo com a inscrição do ano na apresentação do filme: Sertão Brasileiro, 1910. Após a introdução do filme é apresentado depois do fade-out a cartela que indica o mês de fevereiro. Na sequência do filme, os sinais de tempo se dão pelas fases da lua e a mudança de matiz da cor da camisa, até desembocar no fatídico sacrifício em abril, que despedaça o ciclo vingativo. Isso nos importa porque as noções de espaço e tempo desempenham grandioso papel nos ritos religiosos.

No âmbito do tempo, vê-se o ciclo lunar como aquele que marca a trégua de Tonho, mas esse ciclo possui uma tradição de longa data, uma vez que "o ciclo lunar condiciona a vida agrícola, portanto os ritos têm ligação com ela" e "o renascimento da lua é o homólogo simbólico da regeneração da vida vegetal, animal e humana nos prazos breves" (CROATTO, 2010 , p. 345). No caso da narrativa de Salles, a trégua seguida pelo ciclo da lua irradia o renascer de Tonho, que foge do seco e árido sertão e se banha nas águas.

Tonho surge detrás de uma duna de areia. Olha para aquela infinidade, em plano fixo, longo, o ruído da rebentação em off. Novamente o mar, agora em plano geral, o mar enorme, aquele mundo de possibilidades. E um homem que o descobre (SALLES; MACHADO; AIINOUZ, 2002, p. 227, roteiro do filme).

A água encontrada por Tonho simboliza o seu nascer de novo. $O$ tique-taque do relógio que marcava o "menos um" de sua vida e as engrenagens da bolandeira que trituravam sua vida a cada dia, esgotando suas possibilidades morreu junto com esse antigo homem, que descobre, depois de se aventurar pela grandiosa vastidão de espaço além de sua antiga casa, o mundo de possibilidade no instante em que fita aquele mar e se banha nele. $O$ final da trégua simbolizado pela lua desemboca no salvaguardar de Tonho e seu renascer. Enquanto que o espaço vasto nos planos abertos de Salles sublinha a superioridade da natureza e da vastidão do sertão, despertando desse modo, o sentimento de pequenez, ao passo que irradia o desejo de Tonho de adentrar esse espaço vasto de possibilidades.

A substituição sacrificial se passa na história quando o menino veste as roupas de Tonho, coloca em seu braço a faixa preta, veste seu chapéu e decide por andar pela caatinga. Enquanto Mateus está à espreita das terras dos Breves para matar Tonho. "Ele [o menino] parece tomar uma decisão. Em close, as mãos do menino pegam a braçadeira de Tonho. Ele a coloca lentamente no próprio braço. Ele sorri para o irmão, põe o chapéu dele, e parte na imensidão da caatinga" (SALLES; MACHADO AIINOUZ, 2002, p. 226, roteiro do filme). Dessa decisão tomada pelo menino que o sagrado se faz manifesto na história, pois ele, a 
vítima inocente, é dada como substituição para eliminar, controlar e proteger a família, mais especificamente, o irmão Tonho.

O menino avança, sabe o que vai acontecer, e espera pelo tiro.

MENINO [em off]: No mar, eles vivia tão feliz, mas tão feliz, que não conseguia parar de dar risada.

Mateus, atrapalhado, escorrega e perde os óculos.

Ele aponta o revólver, o dedo parece indeciso no gatilho.

E, logo em seguida, a pressão e o eco do tiro (SALLES; MACHADO; AIINOUZ, 2002, p. 226, roteiro do filme).

A morte do menino possibilita o fim desse ciclo de vinganças. $O$ menino é o símbolo da ruptura dessa tradição e orgulho que aprisionava a família e esgotava sua respectiva vida. Ao mesmo tempo, é o libertador de Tonho que, ao notar a morte do irmão, foge pelos portões do fundo de sua casa em direção ao mar. Atravessando toda a caatinga que o cercava até o seu momento de vislumbrar as possibilidades fitando o mar e renascendo dele. Disso decorre o sagrado no filme de Salles. O menino é o cordeiro que, quando imolado, rompe com o ciclo de vinganças que esgotava a vida de todos.

MÃE: Acabou, homem! Acabou, homem! Acabou, homem! Meu Deus, ô, meu Deus!

O casal se abraça, chorando, sós. Tonho se afasta da casa e toma o caminho que ninguém havia tomado até agora (SALLES; MACHADO; AIINOUZ, 2002, p. 227, roteiro do filme).

\section{Considerações finais}

Cada som, luz, enquadramento, fala simboliza algum aspecto que vai além da própria narrativa e ilumina uma dimensão que faz parte do mundo em que os sujeitos habitam, a saber: a dimensão religiosa. No filme Abril Despedaçado de Walter Salles essa dimensão foi elucidada pela construção das personagens apresentadas nessa narrativa, bem como pelos símbolos e enquadramentos específicos selecionados pelo diretor. Nossa tarefa nesse artigo foi, justamente, pormenorizar o modo como esses símbolos e quadros permitiam pensar a dimensão religiosa articulada com a teoria de René Girard.

Na narrativa é visualizado um ciclo de vinganças tradicionalizado que é rompido com o manifestar do sagrado, que se deu pelo sacrifício. Tal realidade aponta para a violência que domina o homem, sendo dominada pela prática ritual em vista da expulsão de qualquer problema que assola uma associação humana, em vista do congregar e apaziguar dos ânimos excitados. Isso se dá pelo fato de existir rivalidade e ressentimento entre sujeitos que desejam certo objeto. Nesse trabalho foi visualizada a rivalidade entre os Breves e os Ferreiras, que anseiam por honra e terra, culminando em um ciclo vingativo que valoriza os ânimos e essa premissa autorreferencial que sempre mata aquele que outrora matou. A ruptura, desse modo, é vista quando há a substituição sacrificial e o sangue do imolado liberta aqueles que estavam presos nesse sistema fechado. A quentura do sangue de Pacu que escorre no árido ambiente de Riacho das Almas é o libertador. Pacu é a vítima sacrificial que rompe com um ciclo autorreferencial de vinganças. Daí deriva o sagrado no filme de Salles.

Se for possível pensar uma teoria da religião a partir desse filme, essa teoria é possibilitada ao compreender que os ritos, símbolos, mitos, testemunhos, rezas e etc. desvelam algo primordial sobre a experiência do homem em seu mundo. $O$ rito apreendido por intermédio dos símbolos da bolandeira, da camisa, do balanço, da lua e dos enquadramentos do sertão sublinham um aspecto do religioso, sobretudo porque coincidem com as dimensões 
de espaço e tempo. $O$ espaço e o tempo habitam o aspecto do religioso, quando no filme, por exemplo, sempre se vê a contradição do amplo espaço do sertão e a figura de Tonho tão pequena diante da imensidão. Assim como no âmbito do tempo se vê os passos transgredidos pelo neto do Sr. Ferreira, culminando na morte de Pacu. Ademais, o renascimento de Tonho, dado pelo sacrifício, aponta para um recomeço. Ou seja, uma nova fase da vida desse homem que decide por se aventurar na vastidão de possibilidades, ao invés de se manter nesse ciclo de esgotamento e anti-horário da vida. Pacu é o agnus dei e Tonho o renascido, o convertido. Esse é o sagrado no filme Abril Despedaçado (2011) de Walter Salles. Disso decorre que a linguagem cinematográfica lança o expectador para o além, ou seja, para o transcendente.

O agnus dei, Pacu, é quem se lança para além do meramente físico e consegue ter uma dimensão do todo, assim como a linguagem cinematográfica de Salles, ao evidenciar a realidades das vendetas e o que está no coração do humano, a saber: a violência. A contenção da violência se deu com o sacrifício de Pacu, libertando Tonho das engrenagens das vendetas. O controle do preventivo está nas mãos humanas. E se para Girard esse controle se dá para o homem dominar aquilo que o domina, esse domínio se dá na ordem do religioso, não podendo estar dissociado da violência. Portanto, o sagrado, em abril, despedaça um ciclo violento em vista do renascimento de um novo homem, Tonho.

\section{Referências}

ABRIL Despedaçado. Direção: Walter Salles. Brasil-França-Suiça: Imagem Filmes, 2001, DVD (95 min). NTSC, son., color., port.

ANSPACH, Mark. R. Anatomia da vingança. figuras elementares da reciprocidade. São Paulo: É Realizações, 2012.

BUTCHER, Pedro. Abril Despedaçado [história de um filme]/ Pedro Butcher; Anna Luiza Müller; roteiro Walter Salles, Sérgio Machado, Karim Aïnouz. São Paulo: Companhia das Letras, 2002.

CROATTO, José Severino Croatto. As linguagens da experiência religiosa. uma introdução à fenomenologia da religião. São Paulo: Paulus, 2010.

ELIADE, Mircea. O sagrado e o Profano. São Paulo: Martins Fontes, 2010.

GIRARD, René. A violência e o sagrado. São Paulo: Universidade Estadual Paulista, 1990. . O bode expiatório. São Paulo: Paulus, 2004

. Mentira Romântica e Verdade Romanesca. São Paulo: É Realizações, 2009.

GUIMARÃES, Lara Marigoni. Tempo, espaço, espectador e leitor: o Abril Despedaçado de Ismail Kadaré e de Walter Salles. Florianópolis, SC, 2014.

PEREIRA, Miguel. Abril Despedaçado. A saga de um santo inocente. In: Revista alceu, v. 12, n. 23, p. 62-70, jul/dez, 2011.

PIEPER, Frederico. Religião e cinema. São Paulo: Fonte Editorial, 2015. 